Article

\title{
Digital Visualisation as a New Driver of Urban Change in Africa
}

\author{
Vanessa Watson \\ School of Architecture, Planning and Geomatics, University of Cape Town, 7700 Cape Town, South Africa; \\ E-Mail: vanessa.watson@uct.ac.za
}

Submitted: 8 March 2020 | Accepted: 17 April 2020 | Published: 26 June 2020

\begin{abstract}
Cities in Sub-Saharan Africa are growing faster than in any other part of the world, driven by expanding informal settlement (usually on the urban periphery) and the real-estate sector aiming for up-market property development. The continent currently has the highest real-estate value growth potential in the world. Much up-market property development is currently taking the form of new 'cities' - sometimes a redevelopment of an entire city (e.g., Kigali), sometimes a new city on an urban edge (e.g., Eko-Atlantic, Lagos) and sometimes a new satellite city (e.g., Tatu City, Nairobi). These projects are driven by international property development companies often in collaboration with governments and sometimes with local planning and property partners. All manifest as plans in a new way: as graphics on the websites of international consultants. Most involve no public participation and attempt to by-pass planning laws and processes. Producing these new plans (as computer generated images) are a new set of professionals: architects, planners, visualisers, advertising executives and project managers, working together in offices in global capitals of the world. Their aim is commercial. Planning in these projects is no longer shaped by the materiality of the city and attempts to achieve socio-spatial justice and sustainability. Rather planning is shaped by the circulation of graphics through a network of software programmes and marketing professionals. This article will situate Africa's new cities in theorisation of urban development and the role of urban planning through digital visualization.
\end{abstract}

\section{Keywords}

digital visualisation; property development; urban Africa; urban inequality; urban planning

\section{Issue}

This article is part of the issue "Visual Communication in Urban Design and Planning: The Impact of Mediatisation(s) on the Construction of Urban Futures" edited by Gabriela Christmann (Leibniz Institute for Research on Society and Space, Germany), Christoph Bernhardt (Leibniz Institute for Research on Society and Space, Germany) and Jörg Stollmann (TU Berlin, Germany).

(C) 2020 by the author; licensee Cogitatio (Lisbon, Portugal). This article is licensed under a Creative Commons Attribution 4.0 International License (CC BY).

\section{Introduction}

The thematic issue this article belongs to argues that the mediatisation and digitalisation of communication processes in urban planning has been taking place with increasing speed. This article suggests that these communication processes are having a major impact on new forms of urban development on the African continent, primarily through their adoption by international real-estate companies embarking on urban mega-projects. These new forms of communication have the main aim of promoting up-market real-estate developments to potential buyers of land and property, but also of inducing governments on the continent to give political and institu- tional support to their land and planning approvals and infrastructure servicing. This planning is very different to the forms of participation and communication long promoted by planning theorists (such as collaborative and communicative planning) which aim at democratic and inclusionary planning processes. The outcomes of these new mediatised and digitalised processes and projects are therefore far more likely to promote urban inequality and exclusion of poorer and less powerful urban residents, although as this article concludes, this does not necessarily have to be the case.

This article addresses the following questions: What new forms of urban planning processes and outcomes are emerging on the African continent? What economic 
and political factors are driving these new approaches to urban development? Which actors and technologies are playing a role in these new approaches and how are they shaping urban outcomes? Finally, what are the implications of these new approaches for future urban development and the key societal and environmental issues which cities face? My research is based on existing published literature on these questions and on website explorations. It concludes that technologies involving CGls (computer generated images) of new urban visions are playing a growing role in what are largely private-sector and profit driven proposals for new urban development. In these design and marketing processes the role of professional planners is changing as well. The potential outcomes of these new forms of planning will be to worsen existing social and economic inequalities in African cities, and to draw policy and planning attention away from meeting urban basic needs and environmental sustainability.

The first section of this article sets out the method. The second section gives a background to urban growth and change on the African continent and how the international real-estate economy has come to play an important role in shaping this development. The third section draws on two areas of theorising which suggest how planning and the role of professional planners in international real-estate companies has changed in recent years. One set of ideas explores 'entrepreneurial' planning and how it contributes to traveling planning ideas from one part of the globe to another. The second set of ideas researches the role of CGls in the production of urban space based on a published case study of a Doha, Qatar, downtown mega-project. The fourth section of the article discusses the implications of this wave of mediatised planning for sustainable and equitable urban development in African cities.

\section{Methodology}

The article is based on secondary sources of information. A literature review was undertaken of reports and published articles on the urban real-estate industry on the African continent, on the role of international urban development consultancies in these projects, and on how these design consultancy firms use new computer technologies and software to produce and market their visions of new urban mega-projects. The published literature on all these aspects, especially in relation to African cities, is limited. The nature of these new forms of urban development has only been recognized and researched in the last six or seven years. Very few of these publications examine the role of new computer technologies in producing visions of these mega-projects. Only one published in-depth, theoretically framed, case study was found on CGIs, the production of urban space and the role of urban design professionals, in an African context. This case study is of the Msheireb Downtown project in Doha, Qatar (see Rose, 2016; Rose, Degen, \& Melhuish,
2014). Qatar is a North African country and hence very different to the rest of Africa, although the African continent itself is so regionally diverse that it would be problematic to generalise from any one case study. However, this article is based on the assumption that the Doha case raises relevant theoretical questions which could be tested in other in-depth case studies on the African continent (on the case study method in Africa see Duminy, Andreasen, Lerise, Odendaal, \& Watson, 2014).

A second source of information for this article was the web. A search was undertaken of the websites of international urban consultancy firms and any African urban mega-projects with which they are involved. Websites on urban mega-projects in Africa were also searched to ascertain the nature of their graphics, design rationales and marketing. This search yielded several potential examples, but the one mega-project referred to in this article is Diamniadio Lake City in Senegal. It illustrates a number of the characteristics of the international consultancy projects described in Rapoport and Hult (2017).

\section{African Urban Change and the Real-Estate Industry}

While rates of urbanisation across the continent are highly variable, in general it is recognized that many African cities are amongst the fastest growing in the world and are likely to experience a doubling of current populations in the next 25 years. Some cities are growing at a rate of $4 \%$ annually. At the same time economic growth and formal job creation have been low relative to other parts of the global South where rapid urbanization and economic development have progressed in tandem (World Bank, 2017). As a result, in Sub-Saharan Africa, urban inequality measured by the Gini coefficient is amongst the highest in the world: $43 \%$ of the urban population live below the poverty line, $60 \%$ of urban jobs are informal and $62 \%$ of the urban population lives in informal settlements (Turok, 2014). Many African countries and cities also have weak systems of public urban management which are poorly financed and capacitated, have complex and competing land tenure systems, and operate through centralised, rigid and outdated planning laws and regulations. Few countries are therefore able to effectively intervene to address critical urban problems and accommodate the rapid rate of expansion, although exceptions (such as Rwanda, Ethiopia and South Africa) do exist.

For these reasons most African cities attracted little in the way of formal private sector investment over the past decades, however that changed significantly after the 2008 financial crisis when global real-estate and infrastructure finance began to look for new markets in emerging economies. With African economies showing a post-2008 revival on the back of a resource boom, urban middle classes have grown and demand (from both domestic and international sources) for formal residential and commercial development have added to global inter- 
est in African urban land and property markets. Africa is now viewed as having the highest potential real-estate value growth from a global perspective (Savills World Research, 2017).

In the years after 2008 this new global interest in investment in African cities became evident in a number of ways. Goodfellow (in press) refers to the rapid growth of foreign investment in infrastructure where risks could be lowered through public-private partnerships and revenue generating. At the same time (and often related) a growth in the urban real-estate market has been led more often by domestic and diasporic investors as there is still much hesitancy from global real-estate investors given high risk factors in many African cities (Savills World Research, 2017). Frequently these two sources of investment combine in urban mega-projects where infrastructure investment creates the potential for rising urban land values and real-estate profits. Goodfellow (in press, p. 13) suggests that the "infrastructuralization" of international finance is feeding into the "real-estatization" of domestic capital, further increasing the significance of urban real-estate. The conceptualisation of urban megaprojects usually lies with global consultancies although they are often financed in partnerships with government or domestic investors. It is not unusual, therefore, to find continental or local consultancies involved in taking forward more detailed real-estate plans from the overarching project conception developed by global companies.

Post-2008, these mega-project proposals emerged into the public realm largely through advertising on the websites of global property investment and engineering consortia. They took the form of glitzy graphics showing up-market commercial and residential developments as new satellite cities, as developments on urban land made available through informal settlement clearance or infill, or even (as in the case of Kigali in Rwanda) as completely rebuilt cities. A substantial literature now exists on these 'fantasy' African cities (Watson, 2014) from the perspectives of their relationship to formal planning systems (Ballard \& Harrison, 2019), their link to economic sectors (Choplin, 2019), their spatial implications (Keeton \& Nijhuis, 2019), the influence of urban policy circulation (Côté-Roy \& Moser, 2019) and their processes of land acquisition (Noorloos, Klaufus, \& Steel, 2019).

These fantasy city proposals have usually involved influential new players in the field of urban planning and design. They tend, at the inception stage, to involve architectural, engineering, property development and planning professionals located in global consultancies with head offices in capitals such as New York and London or, increasingly, in eastern cities. Spatial and architectural plans are developed for identified sites (where land may or may not have been formally acquired) by professionals who may well not have been to the continent at all, and who have been reliant on google earth or other secondary sources to identify contextual informants. There is little or no evidence in the literature on these megaprojects that there has been any form of public par- ticipation or engagement with the full range of stakeholders and those likely to be affected by such projects. Engagement with national and local governments may occur through politicians rather than government officials and often tends to bypass legal and regulatory planning systems. These mega-project proposals then appear on the internet in a very different form to the usual, officially produced, planning and infrastructure technical reports, rather using visualisation through 3D graphics as the primary (and often only) form of communication. Visuals for projects such as those in Kigali, Eco-Atlantic in Lagos, Hope City in Ghana, Kigambone in Dar es Salaam, Tatu City and Konza City in Kenya, and many more, are all examples of these processes. As a result of this shift, planning and design professionals are drawing on new and different skills, are engaging in different work-flow processes and are interacting with each other and with technology in very different ways. This has far-reaching implications both for the impacts of new mega-projects, if they are implemented, and for the social, economic and governance processes which shape them.

Drivers of urban spatial change in Sub-Saharan Africa are numerous and complex, and informal settlement and the informal economy are still the main determinants of spatial growth and change in many countries. The impacts of the current covid-19 pandemic on African economies and on cities will no doubt be significant and are difficult to predict. In the last several years plans for profit-driven urban mega-projects have grown in prominence and many of them are still on plans and websites, yet they promote an image of new urban development embedded in Western (and increasingly Eastern) views of modernist cities. These images will no doubt shape the aspirations of future land developers, both local and international. New digital visualisation processes in urban planning and development are the central vehicle for conveying these images, and how these are developed and circulated is the focus of the next sections.

\section{The Changing Role of Built Environment Professionals through Digital Visualisation}

This section of the article explores the role of digital visualisation in urban planning and development on the African continent from two perspectives. The first examines the role of international property development consultancies in trans-local processes of profit-driven (or entrepreneurial) planning and design. The second considers work-flow processes within such consultancies and the role of CGIs in the production of space. Both these aspects show how the role of planning professionals is very different from what is usually understood to be the case.

\subsection{Entrepreneurial Planning and Design through International Consultancies}

In the fields of urban studies and planning there has been a growing literature on global policy mobilities through 
processes of neoliberal urbanism, in which it is suggested that cities can be remade with reference to imaginings of supposedly successful antecedent urban experiences elsewhere (Bunnell, 2015). These model cities have in the past tended to be European or North American but increasingly they are cities in the Middle East (e.g., Dubai) or East and Far-East Asia (e.g., Singapore and Shanghai). Recent literature also reflects a shift from the idea of policy transfer to policy mobilities (McCann, 2011) which draws attention to the "range of agents, practices and performances involved in the social production and transformative circulation of forms of policy knowledge" (Bunnell, 2015, p. 1988). The work of Rapoport and Hult (2017) focuses on a particular set of these agents and their practices of policy mobility. These are the global intelligence corps (GIC) composed of international private sector architectural, planning and engineering consultant companies which "package up their expertise in urban sustainability as a marketable commodity and apply it on projects around the world" (Rapoport \& Hult, 2017, p. 1779). The authors note how these particular framings of sustainable urbanism have been incorporated into neoliberal agendas of development as economic growth, making it an easy concept to sell to governments and real-estate developers. Also termed ecological modernization theory, it advocates technological advancement and industrialization as a win-win way to solve environmental problems.

Rapoport and Hult's (2017) survey of a large number of GIC professionals explains some significant aspects of this form of master-planning. Firstly, they contain a consistent set of design principles and technologies regardless of location. Tagged as sustainable urbanism, these plans usually indicate high density (glass tower-blocks), mixed-use, landscaped open space and private car and non-motorised movement routes. Hence master-plan graphics from different parts of the world tend to have a 'cut and paste' similarity about them. In some cases, images of existing iconic buildings are positioned within new plans. For example, the 2008 plan for a new Kigali (in Rwanda) contained an image of the London building termed the gherkin (Figure 1). The gherkin was designed by Foster and Partners architectural firm in London for a very different contextual setting. Secondly, the GIC work is completed once the master-plan graphics are done. The project will then be handed over to real-estate developers (local or international) and local built environment professionals to refine depending on the target market. Hence planning professionals play different and usually disconnected roles in the mega-project process, having significant implications for plan processes (especially stakeholder engagement) and outputs. Thirdly, the GIC masterplan is not an end in itself but aims to achieve other objectives such as regulatory approval and investment, both of which will increase the value of land. For all these reasons the role of plans and planners in these mega-projects has changed significantly over the last decade. Detached from on-the-ground informants and stakeholders, and located probably in another part of the world, planners work with other built environment and media professionals to produce standardised graphics of urban visions which conform to the tastes of an up-market elite and lure land investors, and at the same time can be justified as sustainable or smart in terms of a wider development and political agenda.

A current African urban fantasy mega-project in Senegal, called Diamniadio Lake City, provides an example of the characteristics outlined by Rapoport and Hult (2017). This is a new satellite city for some 350,000 people located $20 \mathrm{~km}$ outside of the capital of Dakar and will be close to the new international airport. National government claims that Dakar, at three million people, is overcrowded and congested with "large groups of unemployed workers lingering on street corners" (Bendix, 2018). This emphasis on visual and aesthetic aspects of the capital, which detract from its image as a modern city, is common across most of the African new city plans and lays the ground for proposing new city images which reflect modernity and global city status (Acuto, 2010). Planning approvals for Diamniadio were secured in 2013 but its completion is only planned for 2035 , at a total estimated cost of 2 billion dollars.
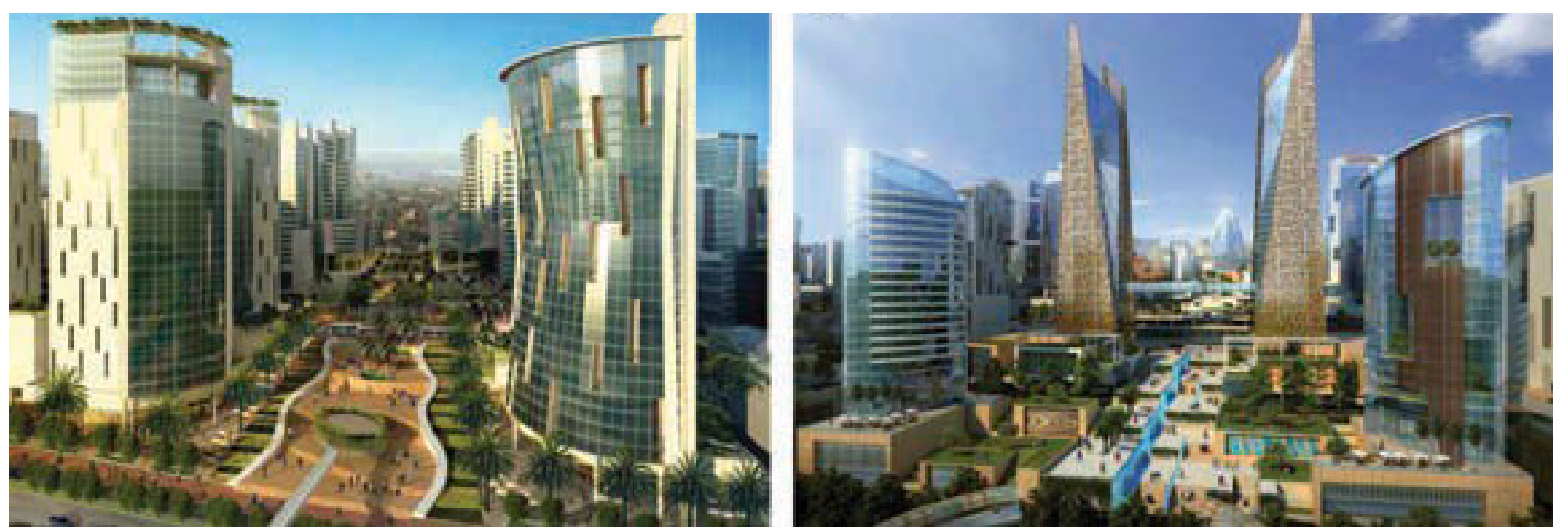

Figure 1. Kigali conceptual master plan (Watson, 2014, p. 218). 
The neoliberal approach to sustainable urbanism is evident in the Diamniadio plan. The city is seen as a component of the 2014 national development plan (Plan for an Emerging Senegal) which takes an economic modernization approach by focussing on economic growth and attracting local and foreign investors. The website graphics for Diamniadio and Figure 2 are extreme versions of futuristic modernism dominated by glass-box tower blocks, landscaped open spaces and water features. Pedestrian and car movement systems show no sign of traffic congestion, informal traders or the "lingering unemployed" (Bendix, 2018) which supposedly make Dakar unattractive to investors and the up-market elite. There are suggestions that the new city promotes sustainability, with the design responding to locally threatened baobab trees by installing green roofs (one graphic shows small strips of grass and dotted trees on rooftops) and facades which accommodate renewable energy (Bendix, 2018). The suggestion that the architecture was inspired by Sengalese culture and landscape is particularly hard to believe. The developers claim that "its sharp curves and sloping lines mimic the amorphous patterns of algae in a nearby lake, as well as the silhouettes of traditional female sculptures" and incorporating copper into each structure connects buildings to the natural landscape (Bendix, 2018).

The plans and architectural graphics for Diamniadio have clearly been developed by professionals with little or no understanding of the real social, economic and environmental issues facing Senegal and Dakar. The entire project is aimed at attracting global investors and wealthy residents, in a country where $46,7 \%$ of the population live below the poverty line (Henyan, 2016). The international real-estate company behind the project, Semer Investment, has its head office in Dubai and states as one of its aims the opening up of opportuni- ties in Africa to the rest of the world. It is likely the professional planning and design outputs were developed from Semer offices, although the architectural renderings, communications media, and website design may have been outsourced elsewhere. It is not clear if Semer has further involvement in the project. It appears that the company sells onwards parcels of land for 'mixed use' to other real-estate developers and there are suggestions that China will be building the industrial park and may set up businesses there. National government seems to have an over-arching role in the project and is undoubtedly funding some basic infrastructure such as the high-speed rail network which will stop in the new city and serve the new minerals port close-by.

It is also not yet clear if construction on the project has started: a recent google earth picture shows the old town of Diamniadio but no sign of new development. Along with many other GIC-initiated urban megaprojects it may be that this one never gets beyond the website graphics. Nonetheless the entire concept and approach to planning as it has been understood in the past, has changed fundamentally in these new urban mega-projects shaped largely by their marketrelated objectives using new communication mechanisms and technologies.

\subsection{The Role of CGIs in the Production of Space}

Within the framework of policy mobilities and international consultants considered above, understanding digital visualisation and planning in urban mega-projects on the African continent also requires an examination of what happens in the professional work-flow process within the companies which produce the proposals. Here, planning and design professionals have their interaction with each other (and with a variety of other

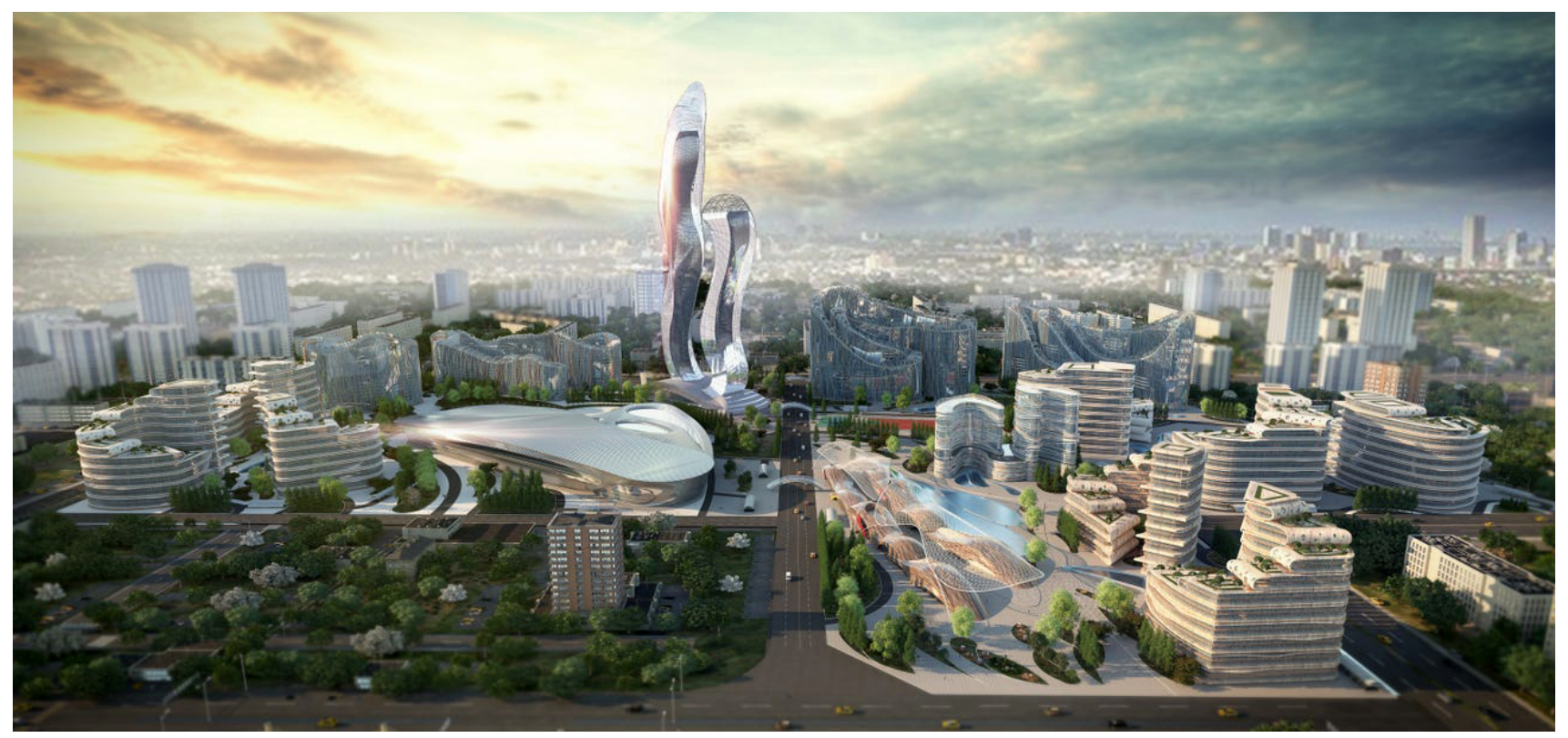

Figure 2. Diamniadio Lake City, Senegal (Bendix, 2018). 
professionals) and their 'output' or 'products' shaped by their relationship to computers and soft-ware codes. This is very different from planners located in state bureaucracies where interactions and outputs are usually driven by rules, regulations, policies and political power, and by bureaucratic divisions, hierarchies and cultures. The work of Gillian Rose and co-authors (see Degen, Melhuish, \& Rose, 2017; Rose, 2016; Rose et al., 2014) on CGls and the production of space, using actor-network theory, is a useful conceptual framework for exploring the work of planners who produce African urban mega-projects.

Rose et al. (2014) argue that rather than explaining the work of CGls by seeing them as simply a marketing tool, as an exertion of affective power through visual images, or through their material influence on cities (as previous research has tended to do), there needs to be a step backwards to understand how these images were, in the first place, shaped in their process of production. These authors consider how CGls circulate through networks and therefore they do not refer to them as images but rather as interfaces which are a series of actions that activate the network. Starting with networks directs attention on CGIs to:

[How] they are made [to show it] as they circulate around a network of offices and computer screens; they are worked on by architects, visualisers, project managers, the client, advertising executives, and others; and the visualisation's digital file thus constantly encounters various software programmes, hardware devices, and human bodies. (Rose et al., 2014, p. 387)

Rose (2016) draws on shifts in the field of cultural geography, and new forms of cultural production, to explain one of these new forms: digital visualisation of new urban developments to show creative professionals (architects, planners), developers, clients and new inhabitants of these developments what they will look and feel like when complete. This requires achieving particular visual qualities to suggest a form of lifestyle and urban aesthetic ultimately needed to sell the urban developments (or parts of them) as commodities. The process of achieving the necessary visual qualities, and making the project desirable to a market, is highly iterative and demands frequent, quick and easy communication (digital and verbal) between creative professionals, and graphic mutability.

Rose and colleagues draw on a case study of the role of CGIs in the planning and design (and marketing) of the 31-hectare downtown regeneration project, called the Msheireb Downtown, in Doha, Qatar (see Rose, 2016; Rose et al., 2014). The developer in this case was Msheireb Properties, a real estate development company, owned by the Qatar Foundation and acting as a source of revenue for the Foundation's other work in education and research. The case shows how 'planning' in these kinds of projects has changed significantly from how it was understood and practiced across much of the African continent until a decade or so ago. Section 3 of this article argues that much new planned urban development in Africa now takes place through the kinds of companies (GICs) involved in the Doha project, sometimes in parallel-or in some kind of interaction withtraditional forms of planning through governments, laws and regulations.

As an illustration of the very different role of planning professionals in processes like the Doha downtown project, Rose et al. (2014) point to the following: Two global urban project companies (UK-based Allies and Morrison and American-based engineering company AECOM) together made a successful 'pitch' to Msheireb Properties (the client) to develop a proposal for Msheireb Downtown. Allies and Morrison is a London based company employing at the time some 300 professionals, mostly architects. AECOM is an international engineering firm with 87,000 employees with headquarters in Los Angeles. The client asked for photorealistic CGIs as they wanted to see the 'look' of the project and to be able to show these to people less able to read plans, maps, and elevations. They also wanted specific visuals to attract future investors. Degen et al. (2017) explain how these digital images aim to evoke and manipulate specific "place atmospheres" and to foreground the "experiential qualities" of the new developments. Moreover, these visual qualities have a dual and related function involving both communicating particular urban aesthetics to future users and being used as a marketing tool. Regarding the latter these authors point to the way in which 'atmosphere' has entered the commercial mainstream as a practice of architectural and urban branding, and marketing, within the context of the "experience economy" (Degen et al., 2017, p. 4). Publications on urban mega-projects and new city proposals across the African continent (see, e.g., Acuto, 2010; Côté-Roy \& Moser, 2019; Watson, 2014) show that Msheireb Properties was not unusual in this request and intent. The majority of these new urban projects are portrayed as visuals of a final built form (rather than maps and plans) on property developer websites with the aim of enticing property investors and middle/upper income buyers. Often the aim is also to secure political support. Hence "computer-generated images (CGIs) have now become the most common type of image media used to visualise and market future urban redevelopments" (Degen et al., 2017, p. 4; emphasis in the original).

A further relevant request from Msheireb Properties was for visual graphics which showed views of streets, squares and public spaces rather than individual buildings or plan layouts. Again, this has become a common feature of website visual graphics in African megaproject and new city proposals. Views are usually oblique aerial shots (fly-by views) or views along streets with buildings lining them: perhaps the view of a potential investor from elsewhere in an arriving plane rather than that of a direct user of the space moving on foot. Some of the websites feature a moving video graphic which starts from an aerial shot and then shifts to closer views. In 
the Msheireb project, Rose et al. (2014) and Degen et al. (2017) describe how this placed particular demands on the relationships between the different creative professionals from the two consultancies, as well as demands on the relationship between them and those involved in marketing the project, and the client. In the past architects, urban planners, urban designers, engineers, property developers and sales personnel had clearly defined roles in new project development and while their products were expected to align, the scales, level of detail, issues and objectives differed. It is no accident that in very many universities across the globe these professions are still taught in different and separate academic departments, and often in different faculties. Graduates may know very little about what other professionals do until they are in the workplace. Academics publish in very different journals and practitioners fall under different and separate professional bodies. These divisions all reinforced past professional roles and work-flow processes.

The new CGI-driven process puts these professionals into a direct relationship with each other and also prioritises the work of some over others. In the Msheireb project (Rose et al., 2014) the demands of the client in Doha were paramount as it had to be persuaded to invest in the project and with the chosen consultants. Interviews with architects revealed their dissatisfaction with the graphics produced for the client as the latter tended to look at the overall image and make a decision on that, rather than on the architecture. This left the architects unclear on how their design process should proceed.

Conventionally architects focus their work on the design of buildings, and urban designers and planners on the public space and overall configuration of spaces and land uses across the project. The client's demand that they be shown views of the streets, squares and public spaces placed more emphasis on the work of the latter professionals with the detailed building designs of the architects perhaps being paid less attention. An intermediary professional here is the visualiser who takes the work of the other built environment professionals to "interpret and execute digitally the place atmosphere suggested by the ALA" (Degen et al., 2017, p. 10). An ALA is an architectural language advisor. The work of the visualiser in this case study is explained as beginning on a CAD file by stripping out architects' design details, leaving something on the screen which looks like a wireframe model. Tensions emerged as the architects wanted to depict their buildings accurately while the visualisers wanted to evoke the life or mood of a future place. To do this, the visualiser would focus on the public space, usually cutting and pasting from online image banks of people, trees and street furniture. In the Msheireb case this caused tension between the visualiser and the client who complained of insufficient Qatari-ness in the street images (Rose et al., 2014). This requirement from a locally based client is probably unusual: Most of the website graphics of project proposals display cut-and-paste im- ages which have no acknowledgement of context at all. Degen et al. (2017) note that despite the contact with the Qatari client the final digital-sensory fabrications were still shaped by a "singular western sensibility."

The ALA added another perspective by requiring more "poetic" images, "atmosphere" and "magic" (Rose et al., 2014, p. 399)-terms which both architects and visualisers found hard to understand but were required to take on board. A further step in the process was carried out through digital rendering which converts a working image into something more like a picture. Rose et al. (2014) explain that this process requires very large amounts of computer processing power and the work may be sent to Chinese render 'farms' where massive computers can be powered by cheap electricity to generate graphics very quickly. The detachment of all these processes from context is evident.

What the Msheireb case shows is how new work-flow processes and client priorities have significantly changed the way in which creative professionals, including planners, play their role and interact with each other and with (and through) their work tools. A significant driver of this change in the Masheireb project, but also in just about all other urban mega-project and new town proposals, is the role of the commercialised, profit-driven real-estate sector. Rapoport and Hult (2017) refer to this as "entrepreneurial planning and design" and Bunnell (2015) as "neoliberal urbanism." Even in mega-project cases where the state has a strong involvement such as Diamniadio Lake City in Senegal in promoting and approving the idea of a new city, much of the implementation and marketing falls to the private sector. This drives the need for speed in proposal production and most importantly the nature and quality of graphics and the audience at which they are directed (developers and investors, or homebuyers). Graphics also need to be produced for different purposes (website graphics, billboards, investor or buyer marketing, and perhaps planning approval) and each of these demands different qualities, forms and methods of production.

In the Msheireb example (Rose et al., 2014) creative professionals worked far more directly with each other than might have traditionally been the case and largely through the medium of their computers and CGIs. They fed into the work of relatively new professionals in the field such as visualisers, language consultants, renderers and marketing executives, with these skills being used to integrate specialist design work and 'interpret' it for the market. In the process it appears that many of the conventional aspects of these professional's work (detailed building design by architects; public space, infrastructure and land use design and definition by urban designers and planners) was air-brushed out of the final product.

For planners some very important aspects of their usual work appear to be missing entirely. The first of these is contextual analysis, providing details of local environmental, economic, social and spatial factors which would normally inform a plan. Planners involved in these 
kinds of projects are often located in offices very far away from the African continent, may never have been there and may know little or nothing about this part of the world. The second is the institutional and public process of planning involving engagement with the state and the various legal and regulatory requirements of planning, and engagement and interaction with civil society i.e., public participation. For these reasons almost all the website graphics of these African mega-projects and new towns appear as strangely context-less. Similar graphics appear for proposals in very different parts of the continent, and many of these graphics are deliberately cut and pasted from online image-banks with pictures of 'iconic' modern cities such as Dubai or Singapore. Context has become irrelevant and dealing with the real and very serious social and environmental issues in current and future African cities is no longer in the job description of planners doing this kind of work.

\section{What New Planning Forms Mean for Future African Cities}

As indicated at the start of this paper, African cities face a particular combination of issues including rapid growth, poverty, unemployment, inequality, poor infrastructure, environmental problems and weak governance (although these vary significantly across the continent). Even though planning systems themselves are often weak and conflicted they offer one clear mechanism through which governments can intervene in how urban futures unfold. This is recognized in the New Urban Agenda, Sustainable Development Goal \#11 which foregrounds urban planning as a policy tool. The kinds of urban mega-projects and new towns discussed in this article do not in any way seek to address these issues, in fact (as in the Diamniadio Lake City case), they directly aim to locate new urban development far away from the "congestion and overcrowding" (Bendix, 2018) of the existing cities, avoiding the aesthetically unfortunate image this creates of lingering unemployed workers on street corners. The new urban projects, driven by profitmotivated private sector developers, rather aim to create completely separate, middle-class enclaves either on newly cleared or created urban land (e.g., Eco Atlantic in Lagos) or in satellite towns well beyond the edges of existing cities (e.g., Tatu and Konza cities in Kenya; Hope City in Ghana and many more). This will greatly exacerbate urban inequalities and draw government infrastructure investment as well as any rates contributions away from existing cities where this is needed most. Graham and Marvin's (2001) "splintered urbanism" (referring to the ways in which the provision of networked urban infrastructural systems can spatially fragment and dislocate the social and economic functioning of cities and regions) is likely to result at a scale yet unseen (Watson, 2015).

However, it is also possible to ask if the technologies and skills involved in CGIs could not be used for other reasons, perhaps as a way of opening up participatory plan- ning processes amongst poorer communities where government or NGOs are working with communities on upgrade proposals? In these situations as well, 'the client' may not easily understand maps, plans or building details, and intended outcomes and processes to get there can be more easily communicated through graphics and videos. A significant difference between these CGIs and ones used by property developers would be a deep and accurate grounding in context and realistic portrayals of planning and building outcomes which communities can understand as affordable and appropriate.

\section{Conclusion}

This article has considered the recent mediatisation and digitalisation of communication processes in urban planning on the African continent. It shows how these technologies have become very much part of a new wave of urban development proposals in and around African cities led by the global property development industry, aimed at a growing middle-class and anticipated rise in urban commercial and retail investors. Urban planning professionals have become incorporated into the generation of these proposals but in ways which place very different demands on their skills, on their relationships to other creative professionals, and on their connection to the context and people for whom they are planning. The traditional notion of planning being in the interest of the public good' is entirely absent in these processes and planners find themselves serving a narrow set of elitist and profit-motivated demands. The new dominance and prevalence of these kinds of urban development projects across the continent is likely to have a highly negative impact on existing cities and towns and create a major setback to the aim of more equitable and sustainable future cities.

\section{Conflict of Interests}

The author declares no conflict of interests.

\section{References}

Acuto, M. (2010). High-rise Dubai urban entrepreneurialism and the technology of symbolic power. Cities, 27, 272-284.

Ballard, R., \& Harrison, P. (2019). Transnational urbanism interrupted: A Chinese developer's attempts to secure approval to build the 'New York of Africa' at Modderfontein, Johannesburg. Environment and Planning A. Advanced online publication. http://dx. doi.org/10.1177/0308518X19853277

Bendix, A. (2018, September 9). Senegal is building a \$2 billion futuristic city to help cut down on overcrowding in Dakar: Check out its abstract design. Business Insider. Retrieved from https://www.businessinsider. com/senegal-building-2-billion-futuristic-cityinspired-by-nature-2018-9? IR=T 
Bunnell, T. (2015). Antecedent cities and interreferencing effects: Learning from and extending beyond critiques of neoliberalisation. Urban Studies, 52(11), 1983-2000.

Choplin, A. (2019). Cementing Africa: Cement flows and city-making along the West African corridor (Accra, Lomé, Cotonou, Lagos). Urban Studies. Advanced online publication. https://doi.org/10.1177/ 0042098019851949

Côté-Roy, L., \& Moser, S. (2019). Does Africa not deserve shiny new cities? The power of seductive rhetoric around new cities in Africa. Urban Studies, 56(12), 2391-2407.

Degen, M., Melhuish, C., \& Rose, G. (2017). Producing place atmospheres digitally: Architecture, digital visualisation practices and the experience economy. Journal of Consumer Culture, 17(1), 3-24.

Duminy, J., Andreasen, J., Lerise, F., Odendaal, N., \& Watson, V. (Eds.). (2014). Planning and the case study method in Africa: The planner in dirty shoes. London: Palgrave MacMillan.

Goodfellow, T. (in press). Finance, infrastructure and urban capital: the political economy of African 'gapfilling.' Review of African Political Economy.

Graham, S., \& Marvin, S., (2001). Splintered urbanism: Networked infrastructures, technological mobilities and the urban condition. London: Routledge.

Henyan, A. (2016). Senegals' poverty status. The Borgen Project. Retrieved from Retrieved from https:// borgenproject.org/senegals-poverty-status

Keeton, B., \& Nijhuis, S. (2019). Spatial challenges in contemporary African new towns and potentials for alternative planning strategies. International Planning Studies, 24(3/4), 218-234.

McCann, E. (2011). Urban policy mobilities and global circuits of knowledge: Toward a research agenda. Annals of the Association of American Geographers, 101(1), 107-130.

Noorloos, F., Klaufus, C., \& Steel, G. (2019). Land in urban debates: Unpacking the grab-development dichotomy. Urban Studies, 56(5), 855-867.

Rapoport, E., \& Hult, A. (2017). The travelling business of sustainable urbanism: International consultants as norm-setters. Environment and Planning A, 49(8), 1779-1796.

Rose, G. (2016). Rethinking the geographies of cultural 'objects' through digital technologies: Interface, network and friction. Progress in Human Geography, 40(3), 334-351.

Rose, G., Degen, M., \& Melhuish, C. (2014). Networks, interfaces, and computer-generated images: Learning from digital visualisations of urban redevelopment projects. Environment and Planning D, 32, 386-403.

Savills World Research. (2017). Global real estate. Trends in the world's largest asset class. London: HSBC Holdings. Retrieved from https://internationalservices. hsbc.com/content/dam/hsbcis/pdf/HSBC_Global_ Real_Estate_Report_July2017.pdf

Turok, I. (2014). Linking urbanisation and development in Africa's economic revival. In S. Parnell \& E. Pieterse (Eds.), Africa's urban revolution (pp. 60-81). London: Zed Books.

Watson, V. (2014). African urban fantasies: Dreams or nightmares? Environment and Urbanization, 26(1), 215-231.

Watson, V. (2015). The allure of 'smart city' rhetoric: India and Africa. Dialogues in Human Geography, 5(1), 36-39.

World Bank. (2017). Africa's cities: Opening doors to the world. Washington, DC: The World Bank.

\section{About the Author}

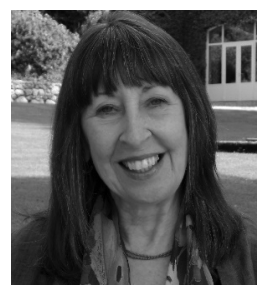

Vanessa Watson is Professor of City Planning in the School of Architecture, Planning and Geomatics, and founder member of the African Centre for Cities, both at the University of Cape Town, South Africa. She holds a PhD from the University of Witwatersrand and is a Fellow of the University of Cape Town. Her research and publications have been on southern perspectives on planning theory, African cities and urbanisation, urban food security and, currently, on planning and corruption in Africa. 